\title{
VIEWPOINTS
}

\section{The Religious Thrust of Islamic Civilisation}

\author{
Mohammad Hashim Kamali*
}

Civilisation implies settlement, to be sedentary or settled in a region, as distinguished from a bedouin or nomadic lifestyle. The renowned historian 'Abd al-Raḥmān Ibn Khaldūn (d. 1406) used haḍārah (civilisation) in the sense of transformation from nomadism to 'umrān, to an urban milieu inhabited by settled populations and societies. The antonym of badāwah (nomadism), hadārah signifies the interaction between man and his environment, and has its genesis in man's quest to harness the existential world around him in the pursuit of worthy objectives. Mankind's mission as God's vicegerent places upon man the responsibility to 'build the earth' in a manner that befits his status as the most honoured of God's creatures. ${ }^{1}$ The English word civilisation is derived from civitas, a Latin term which means 'pertaining to the citizen' or 'a state', thus implying a transformation from nomadism to urbanity and settlement.

The nearest expression to hadāah that features prominently in early Islam is madaniyyah (urbanity, civilisation) and tamaddun, both signifying civilisation and cultural refinement. It is significant that following his well-known migration from Mecca to Medina the Prophet Muhammad (p.b.u.h.) renamed Yathrib as alMadīnah, signifying urbanity and a move away from nomadism. Al-tamaddun alislammiyyah and its Malay equivalent tamaddun Islam are basically synonymous with hadārah islāmiyyah or Islamic civilisation. Civilisation conveys a sense of historical presence in the global arena of settled societies and their engagement with the outside world and other civilisations. Islam's glory and the greatness of the ummah will be restored through physical development that is complemented by human development."

Civilisation is an advanced stage or system of social development involving cultural refinement, the arts and other manifestations of human intellectual endeavours. ${ }^{3}$ Civilisation subsumes the cultural and customary traditions of peoples and communities but since culture and custom can also include undesirable features, civilisation generally references only the positive achievements of cultural and customary practices. In comparison to civilisation, culture (thaqāfah) is a narrower concept. Hence one may speak of Malaysia's culture or customs but since it is a part of the larger ummah, it shares with the latter the characteristics of one and the same Islamic civilisation. 
The Islamic discourse in the Arab world in recent years has been teeming with such phrases, for instance, as al-mashrū' al-hadārī (civilisational plan/ programme) and wa'y al-hadāar (civilisational awareness), but more interestingly also tathqüf al-haḍarī (building a civilisational culture). There is a clear effort aimed at enhancing the awareness of the broader civilisational values that are part and parcel of the outlook of individuals and which also (ideally) manifests itself in their conduct. Civilisation is the outlook of the larger community while culture is the manifestation of the civilised perspective in the conduct of the individual. ${ }^{4}$

Malik Bennabi (d. 1973) has characterised civilisation as the sum-total of the moral and material means that enable a society to provide each of its members with all the social support services needed by him to progress. Civilisation as such is not merely a matter of economic and technical progress. It is rather the product of dynamic, integrated and concrete elements, the most important of which, according to Bennabi, is the moral, where morality is anchored in the structure of values provided by religion. ${ }^{5}$

Comparing the 'realm of objects' with the 'realm of ideas', Bennabi considered it historically proven that when a society possessed a good balance of ideas, objects and commodities could easily be created. For example, Germany's infrastructure was totally destroyed during the Second World War and its people had lost their 'realm of objects'. However, because they were still in control of their 'realm of ideas' they were able to reconstruct and restore its position of European leadership. On the other hand, "accumulating the products of one civilisation could never create a civilisation for another society". ${ }^{6}$ Bennabi added: "civilisation cannot sell its spirit, ideas, intimate wealth, tastes [...] and notion of meaning." For Muslims and the Third World, the mistake was that after political independence, they promoted an object-based civilisation (hadārah shay'iyyah) based on the accumulation of objects and importing of material commodities reinforcing their inability to create and produce. ${ }^{7}$

In Yūsuf al-Qaraḍāî̄'s view, Islamic civilisation mirrors the identity and self-image of the ummah, its beliefs, values, laws, customs and cultural heritage. "It is impermissible for an ummah of such a distinctive identity and mission to melt itself into an alien civilisation". ${ }^{8}$ Building the earth ('imārat al-ard $)^{9}$ is one of the cardinal civilisational missions of Islam, and the principal Qur'anic responsibility of the vicegerency of man on the earth (al-Nur, 24:55). This divine responsibility requires the worship of God and compliance with His commands and prohibitions (51:56).

The Qur'anic foundation of hadārah, namely making the earth prosperous ('imārat al-arḍ), according to Ramaḍān al-Būț̣i ${ }^{10}$ consists in its broadest sense of building a sound and humane social order (mujtama 'insānī islāmì), administration of justice, and the pursuit of knowledge. The moral and spiritual dimensions 
of a sound social order are grounded in tazkiyah and falah (purity and spiritual attainment) and in fighting corruption (35:18; 87:14). The Qur'anic supplication taught to Muslims, asking God the Most High to "grant us good in this world and good in the hereafter" (al-Baqarah, 2:201), is a directive to the believers to "strive in your worldly affairs as if you will live forever, and strive in your affairs of the hereafter as if you will die tomorrow". "11 This prompted the earliest Muslims to establish government and develop culture in the widest sense. Muslims are accordingly deeply convinced that what happens in this life is of inescapable and lasting civilisational significance. The building of an appropriate community life on earth is therefore a religious imperative. ${ }^{12}$ Yet Islamic civilisation is by and large a 'civilisation of values and principles' (hadārat qiyām wa mafāhìm), not one of externalities and forms. ${ }^{13}$

Recourse to illegitimate violence is alien to Islamic teachings. Terrorism (hiräbah) is a capital offence, which can never be equated with the struggle for a just cause (jihād), and subject of a decisive Qur'anic injunction (al-Ma'idah 5:33). But it is unfortunate that distortion and confusion have proliferated and the limits of culture and law have been transgressed by recourse to unjustified aggression and violence by state parties and individuals in recent years. Without wishing to delve into details, illegitimate violence has been resolutely condemned in the Mecca Declaration of the OIC Islamic Summit of the 57 heads of states and governments (December 2005) that declared: "We affirm our unwavering rejection of terrorism, and all forms of extremism and violence". The document draws attention to the broader objectives of Islamic civilisation:

Islamic civilisation is an integral part of human civilisation, based on the ideals of dialogue, moderation, justice, righteousness, and tolerance as noble human values that counteract bigotry, isolationism, tyranny and exclusion. It is therefore of paramount importance to celebrate and consecrate these magnanimous values in our Muslim discourse within and outside our societies. ${ }^{14}$

Both Ibn Khaldūn and Bennabi placed great emphasis on the role of religion in founding a civilisation. Ibn Khaldūn held the view that piety moderates envy and avarice and it is therefore essential for the formation of a state. Bennabi thought that religion was a prerequisite of any civilisation. It was the catalyst that gave humanity the spark to start a cycle of civilisations. ${ }^{15}$ Bennabi observed also that while Christianity, which is the cradle of western civilisation, began its development long before Islam, Islamic civilisation came to flourish much sooner. Civilisation, he continued, is born twice: first, when the religious idea itself is born and, second, when the idea becomes recorded and internalised in the souls of men and women and begins to shape events and therefore the course of history. Islamic civilisation had "both births" at once, in part due to the emptiness that 
Islam found in the virgin souls of the Arabs. Christianity, by contrast, appeared in the midst of several different religions and cultures: Hebrew, Roman and Greek. This prevented Christianity from playing a seminal role in the development of a civilisation until it reached the Germanic tribes of Northern Europe. ${ }^{16}$

Toynbee and Bennabi both adopted the Khaldūnian pattern of birth, growth and decay of civilisations. Both believed that social decline was caused mainly by faulty but curable elements within a civilisation - hence its ability to initiate a new cycle of growth. In support of this, Bennabi quoted the Qur'anic verse: "God does not change a people's condition unless they change that which is in themselves" (13:11). Decline and destruction usually take place from within, as expressed in Toynbee's often-quoted phrase: "civilisations perish through suicide but not by murder". ${ }^{17}$

In sum, the civilisational thrust of Islam is founded on the Qur'anic principle of the vicegerency of man on the earth, to be fulfilled through developing the earth and a social order therein that is grounded in moral uprightness, compassion (rahmah), beneficence (ihsānn), human dignity and justice (karāmah, ' $a d l$ ). The Qur'an also commits the Muslims to the promotion of what is fair and the prevention of what is unfair/rejected (amr bi'l-ma'rüf wa nahy 'an almunkar), upholding the common good (mașlahah) of the people. It is emphatic on the maintenance of the ties of kinship, honouring one's neighbours, rigorous pursuit of knowledge, earning of one's living through lawful work, and helping the needy. The principle of Divine Oneness (tawhi $\bar{d}$ ) advocates a unitarian vision of humanity without discrimination of any kind - moral excellence being the only criterion of distinction in the eyes of God. Mutual recognition (ta'arruf) among nations, cooperation in good works, and fraternity (ta'āwun, ukhuwwah) constitute the conceptual framework of the vicegerency of man on earth.

\section{Notes}

* Mohammad Hashim Kamali, Founding Chairman and CEO of IAIS Malaysia, graduated from Kabul University, and took his $\mathrm{PhD}$ in Islamic and Middle Eastern Law at the University of London in 1969. Professor Dr M.H. Kamali served as Professor of Islamic Law and Jurisprudence at the International Islamic University Malaysia (IIUM, 1985-2007), then Dean of the International Institute of Islamic Thought and Civilization (ISTAC). He also held Visiting Professorships at McGill University's Institute of Islamic Studies; Capital University, Ohio; and the Wissenschaftskolleg, Berlin. A member of the Constitution Review Commission of Afghanistan (2003), he has provided expert legal consultation to the new constitutions of Iraq, the Maldives and Somalia. Eminent authority on Islamic legal studies, he has published over 150 academic articles and 35 texts, including standard textbooks at universities worldwide. 
1. Muḥammad Sa '̄id Ramaḍān al-Būṭī, Manhaj al-haḍ̂arah al-insāniyyah fì'lQur'ān (Beirut: Dār al-Fikr al-Mu'āșir, 1426 AH/2005), 19-20.

2. Prime Minister's speech “A Giant Step for the Malays” The Star [Kuala Lumpur] (22 July 2005), at 34 Nation.

3. Readers Digest, Complete Word Finder (Oxford: Oxford University Press, 1990).

4. Cf., Shīrīn Hamīd Fahmī, "Manzurunā al-islāmī al-ḥaḍārī”, 1, available online http://www.islamonline.net/arabic/contemporary/2005/09/article04.html (accessed on 8 September 2008).

5. Malik Bennabi, Mushkilāt al-Afkār fìl'l-'àlam al-Islāmī (Cairo: Maktabah 'Ammān, 1971), 50.

6. Fawzia Barium, Malik Bennabi, His Life and Theory of Civilisation (Kuala Lumpur: Budaya Ilmu, 1993), 163-164.

7. Ibid., 165.

8. Yūsuf al-Qaraḍāwī, Ummatunā Bayna Qarnayn (Cairo: Dār al-Shurūq, 1427 $\mathrm{AH} / 2006,3^{\text {rd }}$ ed.), 10.

9. "He it is Who created you from the earth and made it your mission to build it" (Hud, 11:61).

10. Al-Būṭi, Manhaj, 24-25.

11. A saying of the caliph ${ }^{\mathrm{c} A} \mathrm{~A} \overline{1} \mathrm{~b}$. Abī Țālib, cousin and son-in-law of the Prophet.

12. Cf., Imam Feisal Abdul Rauf, What's Right With Islam is What's Right With America. A New Visions for Muslims and the West (New York: HarperSan Francisco, 2004), 177.

13. 'Abd al-Majīd al-Ṣaghir, "Isti’nāf al-murājacah al-naqdiyyah al-taḥlīliyyah liturāthinā al-islāmī," Al-Ihyā' 26 (Shawwāl 1428 AH/November 2007), 42.

14. "Makkah al-Mukarramah Declaration", Third Extraordinary Session of the Islamic Summit Conference (5-7 Dhü'l Qa'dah 1426 AH/7-8 December 2005), 3.

15. Ibid., 118-120.

16. Malik Bennabi, Shurūt al-Nahḍh (Damascus: Dār al-Fikr, 1979), 41.

17. Quoted in Fawzia Barium, Malik Bennabi, 132. 